\title{
ABSTRACTS OF FOREIGIN MEMOIRS.
}

Beobachtungen tm mittleren Jera des Badischen Oberlandes, von F. SANdBERGER. pp. 22. (From the Würzburger naturwissenschaftl. Zeitschrift, rol. v.) [Observations on the Middle Jura of the Upland of the Duchy of Baden.]

THE Chain of the Jura, broken asunder at right angles to admit the passage of the Rhine, is continued towards the north-east into the Duchy of Baden, but the typical Jurassic rocks are somewhat changed. Fromherz in 1838, and afterwards in 1853 , gave a correct outline of the strata, and their relations with their Swabian and Swiss analogues. The author of the present memoir in $1856 \mathrm{had}$ occasion to go over the ground again, and found a Nerinæa-bed above the so-called Great Oolite. He was thus enabled to correct the nomenclature, and adapt it to the modern state of science. He has since pursued his investigations, and now gives the following as the series, in descending order. No representatives of the Kimmeridge beds have been detected.

11. Coral-limestone of Istein, Kleinkems, \&c. (Coral-rag) Corallien of I'Orbigny.

10. Marl, with Ammonites cordatus. (Oxford Clay.) MHDLE 9? Grey clay, with pyritous nodules; at Müllheim. $\}$ Callovien, OoLITE.

8. Ferruginous marl, with Ammonites macrocephalus. $\int$ D'Orb.

7. Cornbrash.

6. Marly oolite, with Ammonites ferruginens.

$\{$ Bathonien, D'Orb. LowER

5. Large-grained oolite, with Nerince Bruckneri.

4. White small-grained oolite, with Ostrea acuminata and Echinobrissus Renggeri.

3. Limestone, with Ammonites Humphriesianus.

2. Sandstone and ferruginous limestone, with $A m$. Murchisona.

1. Clay, with $A m$. opalinus.

Bajocien, D'Orb.

LOWER OOLITE,

Lower Division.

Carefully prepared tables of the fossils, and a description of some new species, add to the value of this memoir. The following are the names of the new species :--Waldheimia bicincta, Rhynchonella semiglobosa, Opis calva, Pleurotomaria disparitexta.-D. T. A.

UEBer organische Ueberreste in DEM DAchschiefer voN WuRzach bei LoBENSTEIN. [On Fossils in the Roofing-slate of Wurzbach, near Lobenstein, Thüringerwald.] By Dr. Geinitz. 9 pages, with 2 plates. (From the Nenes Jahrbuch, 1864. Heft 1.)

THIS paper treats of some few fossils found in the Wurzbach Slate 1 by Bergmeister Hartung, of Lobenstein (Duchy of Reuss), by which the author determines that this slate or schist is of Silurian and not Devonian age. Most of these fossils are such as have been usually referred to the trails of Annelids and to the gallery-tracks of Crustaceans. 1. Gordia marina, Emmons, found also in the 'Taconic' schists of North America. 2. A riband-shaped wormlike fossil, figured in pl. 1, fig. 1 and 1A. 3. Crassopodia Thuringiaca, Gein., pl. 1, fig. 2. 4. A worm-like body (pl. 2, fig. 3) 
similar to Nereites lanceolata, Emmons. 5. Nereograpsus Jachsoni, Emmons, sp. This is figured in pl. 2, fig. 4. 6. Lophoctenium Hartungi, Geiu. (pl. 2, fig. 5), differing somewhat from L. Richteri, which occurs in the Silurian rocks at Saalfeld, together with Nereo. grapsus Cambrensis and $N$. pugnus. 7. Crinoidal remains (indeterminable). 8. Sagenaria? (pl. 1, fig. 6), a fragment of stem, 28 centim. long, and referable either to Sagenaria, or Lycopodites, or some other Lycopodiaceous form. Two Graptolites (Monograpsus priodon and $\boldsymbol{M}$. peregrinus) also have been found in these Wurzbach slates; thus eliminating from the indefinite 'Grauwacké' of Central Germany another patch of Silurian strata. Professor Geinitz, in describing the above-mentioned fossils, states that he is confirmed in his views of the relationship of Nereograpsus to the Graptolite family, with Funiculina cylindrica, Blainville, as its analogue; and of Lophoctenium to Sertularida.-T. R. J.

Uerer ein neues Erdharz, Euosmtt, aus minem Braunkohten-Tager bei Thumsenteuth in der Bayer. Oberpealz. Von Herrn Dr. C. W. Gümbel. [On a new Fossil Resin (Euosmite) from a bed of Brown-coal near 'Thumsenreuth, in the Upper Palatinate, Bavaria. By Dr. C. W. Gümbel.] (Neues Jahrbuch für Min., Geol., \&e. Jahrg. 1864. Heft 1. pp. 10-14.)

IN small isolated troughs upon the basalt which extends from 1 Bohemia westwards, between the Fichtelgebirge and the Oberpfälzer-Wald, there occurs a Browncoal-formation, in contact with other Tertiary deposits, which is easily distinguished from others by scarcity of animal remains both in the Browncoal itself and the associated beds, and especially by the entire absence of Shells. In the bituminous shale of the Clausen, however, near Leussen, not far from Redwitz, there are not unfrequently found Fishes (Leuciscus papyraceus and Lebias gobio), Dragon-flies, Beetles (Bruchus, Buprestis, Nemotales), and other organisms. Plant-remains, on the other hand, are everywhere abundant, and are often very well preserved, in consequence of having undergone a kind of silicification. Beds of Diatomacea of a considerable thickness also occur. Usually the beds of Browncoal are overlain by a deposit of bog-iron-ore; and in some places earthy phosphorite occurs in the associated strata.

Respecting the Browncoal itself, Dr. Gümbel observes that it is composed partly of soft, earthy, nearly useless coaly masses, and partly of very good lignite. In it are found, besides numerous stems, Glyptosirophus Europaus, Acer tricuspidatus, Juglans rostrata, $J$. ventricosa, and in extraordinary numbers the little fruit, Folliculites Kaltenhordheimensis.

It was in a Browncoal-formation at the Baiershof, near Thumsenreuth, not far from Erbendorf, in the Oberpfalz, having these general characters, that the fossil resin was found, of which $\mathrm{Dr}$. Gümbel, after describing in detail the strata of that locality, next proceeds to give the characters.

Most Browncoal-formations have yielded fossil resins; but that of Thumsenreuth is easily distinguished from them, by a very strong and peculiar smell, which caused the miners to give it the name 
of 'Kampferharz,' the odour being very similar to that of Camphor, and at the same time resembling that of Rosemary. It occurs either in brownish-yellow, almost pulverulent masses, or in nearly firm pieces, of the colour of cherrytree-gum, and looking like ordinary pitch; in both states it has the same pleasant odour. It is brittle, translucent in thin films, becomes strongly electric when rubbed, and has a conchoidal fracture. Its hardness is $1 \cdot 5$, and its specific gravity $1 \cdot 2-1 \cdot 5$. Its composition, excluding 0.84 per cent. of ash, is, according to Dr. Wittstein, as follows:-Carbon 81.89 ; Hydrogen $11 \cdot 73$; Oxygen $6 \cdot 38=100 \cdot 00$. This corresponds to the formula $\mathrm{C}_{34} \mathrm{H}_{29} \mathrm{O}_{2}$, and shows the resin to be most nearly related to that from Giron in New Granada, which was analyzed by Boussingault ; * but it is distinguished from that species by its aromatic smell, and its being very easily soluble, without leaving auy residue, both in alcohol and ether. The author then proceeds to give in more detail the effect of chemical reagents and solvents upon the resin, and states that, as he cannot reconcile its behaviour under their action, nor its peculiar smell, with the characters of any known species, he ventures to bestow upon it the name of Euosmite.

Euosmite is generally found filling up clefts and rents in the lignite, in such a manner as to leave litle doubt that the wood forming the lignite belonged to the tree which produced the resin. A microscopic examination of these pieces of lignite has shown that it consists of coniferous wood very similar to that of Cupressinoxylon subarquale, Goeppert, and doubtless belonging to a closely allied species, with the characters of which Dr. Gümbel concludes his paper.-H. M.J.

Leonitard und Geinitz's Netes Jahrbetch für Mineralogie, Geologie, und PALEONTOLOGLE. Jahrgang 1864. Heft 5 .

THIS number of the Jahrbuch contains six original memoirs, 1 besides the usual miscellaneous matter. The first two papers are by Dr. Geinitz, forming additional contributions towards a complete history of the Permian fauna and flora; they are:-

1. 'Palcosiren Beinerti, Gein., Ein neues Keptil aus der unteren Dyas von Oelberg bei Braunau' (Prlacosiren Beinerti, Gein., a new Reptile from the Lower Dyas of Oelberg near Braunau). 2. 'Zwei Arten von Spongillopsis, Grein.' ('Two species of Spongillopsis, Gein.) These papers necessarily consist almost entirely of detailed descriptions of the fossils; it will therefore be sufficient to state that Palaosiren Beinerti is considered by Dr. Geinitz to be most nearly allied to the existing Salamander-Siren lacertina, L., and the two species of Spongillopsis (S.dyadica and S.carbonica) to the living Spongilla fluviatilis, Blainv.

The remaining papers are the following:-

3. "Ueber die Stellung des "Terrain à Chailles" in der Schichtenfolge der Juraformation' (On the stratigraphical position of the 'Terrain à Chailles' in the Jurassic Formation), by M. Peter Merian. 
The 'Terrain à Chailles' (so named by 'Thurmann on account of its containing siliceous particles, which are locally termed 'Chailles') is one of the inconstant minor subdivisions of the Middle or Upper Jura, and occurs in the Cantons of Basel, Solothurn, and Berne, as well as in the neighbouring French Jurassic area. It is rich in wellpreserved fossil remains, more especially of Corals, besides Crinoids and Echinoderms, but Cephalopods are rare; the whole assemblage constitutes, however, a peculiar and very distinct fauna. Of the Echinoderms, the most important being Cidaris Blumenbachii, Ag. (C. Alorigemma, Phill.), C. cervicalis, Ag., Hemicidaris crenularis, Ag., and Glypticus hieroglyphicus, Ag., scarcely a single species is known to the author to occur on any other horizon. For this and other reasons, which are given by $\mathbf{M}$. Merian in detail, he considers the 'Terrain à Chailles' to be the equivalent of the Crenularis-beds (so-named by Herr Mösch, from the occurrence in them of the Hemicidaris crenularis, Ag.) of the 'White Jura' of the Canton Aargau, the above-named characteristic species of that formation occurring therein in company with Stomechinus perlatus, Desm., and Diplopodia Annonii, Des.

The position of the Crenularis-beds is shown in the following table of the Aargau Jura, the beds being given in descending order : -

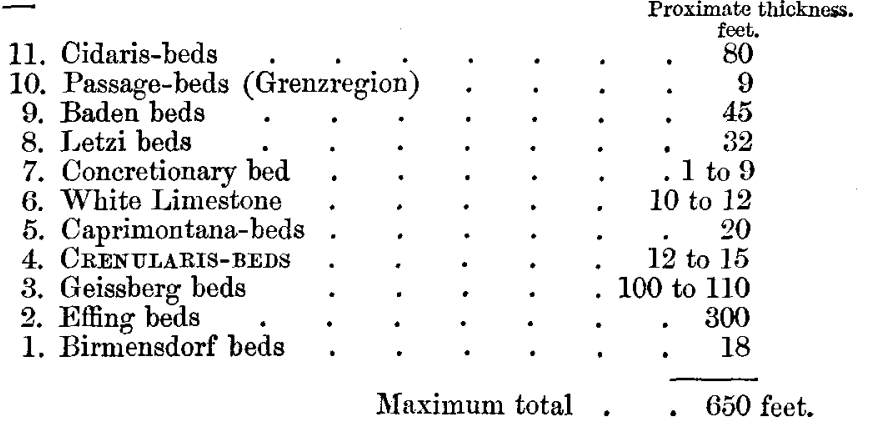

The Birmensdorf beds, forming the lowest member of the serics, repose immediately on the Ornatus-clay, - the "I'errain Callovien' of D'Orbigny.

4. 'Ueber den Zwillingsbau des Quarzes' (On Twin-crystals of Quartz), by Dr. Friedrich Scharff. With two Plates. In this paper the author discusses, at great length, the question whether twincrystals of Quartz are really known to exist, and he comes to the conclusion that, while certain crystals, obtained from Flöha and from Munzig, appear to establish the fact of the existence of such formations; yet there is sufficient evidence to cast doubt on the supposed twin-character of certain other double crystals of that mineral; and he further remarks that the statement of Weiss, to the effect that Quartz is but rarely disposed to form twin-crystals, has received confirmation on all sides.

5. ' Ein Beitrag zur Kenntniss des Versteinerungs-Zustandes der 
Crinoideenreste' (A contribution to the knowledge of the fossil state of Crinoid-remains), by Herr A. W. Stelzner. With one Plate. This paper is a contribution to our knowledge of the microscopic structure of Crinoidal remains, and of the causes which produce the peculiar crystallization that has for so long been known to characterize Echinoderms. The author first gives a critical notice of the various essays on the subject, which have appeared since that of Hessel* in 1826, and then describes in detail the appearances under the microscope presented by prepared longitudinal and transverse sections of the stems and arms of several species of Crinoids. The conclusion to which the author arrives is identical with that enuneiated by Dr. Carpenter in 'The Microscope and its Revelations' (p. 345), and quoted in a postscript by Herr Stelzner, who, it appears, was not aware that so much had been done in this direction until after his paper was written; this conclusion may be thus stated: In the cylindrical stems of Encrinites the calcareous network is uniform throughout, or very nearly so; but in the five-sided Pentacrinites a determinate pattern is formed, through a difference of texture in various parts of the cross-section, and these patterns, although always belonging to one general type, are nevertheless sufficiently different to be recognized apart on an examination of the transverse sections of different stem-joints.

6. -Ueber die Entstehung des Travertins in den Wasserfällen von 'Tivoli' (On the Origin of the Travertin in the Cascades of Tivoli), by Dr. Ferdinand Cohn. The Travertin of the neighbourhood of 'Tivoli comprises four varieties, and in this paper the author discusses at length the origin of two of them, namely, the 'Shaly Travertin,' and the 'Confetto,' giving merely a sketch of the characters of the other two-the 'Thick 'Travertin' or the Travertin of architecture, and the so-called 'Alabaster' of the Roman artists.

'The 'shaly' variety consists of a succession of beds of more or less earthy carbonate of lime, and composed of a great number of cylinders of travertin, each of which has been formed in concentric layers round a vegetable nucleus. The author is of opinion that the plants are the primary cause of the deposition of the carbonate of lime, but that the subsequent stages in the formation of the deposit are altogether unconnected with organic laws. In support of this opinion he observes that, if the cause of the deposition of carbonate of lime were merely the exposure of the water to the atmosphere, the deposit would first appear upon the surface as a film,-which is not the fact in this case, although it is so at the thermal springs of Karlsbad, \&c.

Respecting the eecond variety of Travertin, Dr. Cohn strives to show that its deposition is not owing to the sulphurous acid which emanates from the Solfatara of Tivoli, in which it is formed, as on analysis he found it to contain no sulphides, but only carbonates.

H. M. J.

* Einfluss des organischen Körpers auf den unorganischen, nachgewiesen an Enkriniten, Pentakriniten und anderen Thierversteinerungen. Marburg, 1826.

VOL. I.-NO. VI. 